\title{
EFFECT OF USING PRICKLY PEAR AS A SOURCE OF DIETARY FEEDSTUFFS ON PRODUCTIVE PERFORMANCE, PHYSIOLOGICAL TRAITS AND IMMUNE RESPONSE OF RABBIT. 2- PRICKLY PEAR PEELS
}

\author{
Battaa A. M. El-Neney ${ }^{1}$, Kh. I. I. Zeedan ${ }^{2}$, E. M. El-Kotamy ${ }^{2}$, Ghada G. Gad ${ }^{3}$ and A. Abdou ${ }^{4}$ \\ ${ }^{1}$ Department of Poultry Nutrition Research. Animal Production Research Institute, Agricultural Research \\ Centre, Dokki, Giza, Egypt. Corresponding author email: drbattaaelneny@yahoo.com \\ ${ }^{2}$ Department of Animal Nutrition Research, Animal Production Research Institute, Agricultural Research \\ Centre, Dokki, Giza, Egypt. \\ ${ }^{3}$ Poultry Production Dept., Faculty of Agriculture, Ain Shams Univ., Egypt. \\ ${ }^{4}$ Animal Production Dept., Faculty of Agriculture, Ain Shams Univ., Egypt.
}

(Received 3/2/2019, accepted 7/3/2019)

\section{SUMMARY}

$\mathrm{T}$ The present study aimed to determine the effects of using different level of prickly pear peels byproduct as an unconventional ingredient in the different of rabbits on productive performance, digestibility, some blood constituents, immune response, activity of certain digestive enzymes in pancreatic tissue and intestinal contents and economic of efficiency. Sixty weaned New Zealand White rabbits (NZW) male rabbits aged 35 days and weighed $600 \mathrm{~g} \pm 2.20$ were equally and randomly divided into four groups (15 in each one). The experimental diets contained different levels of dried prickly pear peels (PPP) $(0.0$ control (C), 10, 20 and 30\%), respectively. Results indicated that: The final live body weight, total weight gain and performance index were significantly $(\mathrm{P}<0.05)$ affected by PPP groups. The highest $(\mathrm{P}<0.05)$ values of live body weight, total weight gain and performance index were recorded by rabbits fed 30\% PPP inclusion (2178g, $1577 \mathrm{~g}$ and $74.59 \%)$ followed by received inclusion level of $20 \%$ PPP $(2080 \mathrm{~g}, 1482 \mathrm{~g}$ and $66.45 \%)$, respectively compared with the $10 \%$ PPP $(2000 \mathrm{~g}, 1398 \mathrm{~g}$ and $58.82 \%)$ or control $(1990 \mathrm{~g}, 1390 \mathrm{~g}$ and $56.37 \%)$, respectively. Feed intake ( $\mathrm{g} /$ day), protein intake, and digestible energy intake were significantly $(\mathrm{P} \leq 0.05)$ decreased with increasing PPP levels. Rabbits fed PPP (30\%) diet recorded a significant best FCR value followed by those of 20 and $10 \%$ tested material, respectively. Digestibility coefficient and nutritive values (DM, CP, EE, CF, TDN, DCP and DE) were significantly improved for rabbits fed diet contained PPP compared to those fed the control diet. There were significant increases detected for plasma total protein, albumin and globulin while blood plasma of total lipids was significantly decreased by increasing PPP inclusion level compared to control groups. Liver function as AST and ALT activity were not affected by dietary treatments with supplementing PPP. Values of each of blood components including (red and white blood cells count) and hemoglobin were increased in rabbits fed diet contained PPP than those of the control, Also there is a significant increase in the activity of intestinal amylase, lipase and protease in rabbits compared to controls. Moreover the concentrations of $\mathrm{IgG}$ and IgM of rabbits were higher for rabbit supplemented with PPP than the control group. The best economical efficiency and relative economical efficiency values had been recorded with rabbits fed $30 \%$ PPP inclusion followed by rabbits received $20 \%$ and $10 \%$ treatment of PPP, respectively. It is concluded that supplemental dried prickly pear peels (PPP) at the rate of 30 or $20 \%$ of the diet improved growth performance and health status of the NZW rabbits.

Keywords: Prickly pear peels, growth performance, digestibility, rabbits and diet.

\section{INTRODUCTION}

Plant sources including grains, vegetables, fruit and medicinal herb have potentially received increasing attention recently for their role in the prevention of human diseases. Recently, there has been considerable interest to find naturally antioxidants to be use in foods, cosmetics, or medicinal materials in order to replacing synthetic ones, whose use is being restricted due to their carcinogenic effects (Abdel-Hameed 


\section{El-Neney et al.}

et al. 2013). Prickly pear plant is one of most important sources that used in agriculture sustainable development as a potential alternative crop for arid and semi-arid regions. Minimizing the feed cost could be achieved through the use of untraditional cheaper feed ingredients or improving utilization of common feeds by using some additives or supplements. Attention therefore should be drawn towards the use of some local by- products available in certain areas of Egypt. For instance, a relatively great quantity of prickly pear peel (PPP) which is accumulating after harvesting its fruits that can cause environmental pollution. Prickly pear peels are widely used as animal feed ingredient after a possible suitable processes (Felker, 1995; Ali, 2001 and El-Nagmy et al., 2001).

In Egypt, the total production of prickly pear are nearly 31671 ton, while the peel represents about $45 \%$ of the fruit weight, therefore, the total amount of peel being accounting by 14252 ton/ year (EAS, 2012). Peels represent a large proportion of the whole fruit (from $40 \%$ to 50\%) and constitute a source of bioactive compounds, such as phenolics and flavonoids compounds (Kuti, 2004, Arrizon, et al., 2006 and El-Beltagi, et. al. 2019). Prickly pear fruit is a berry typically weighs 100 to $200 \mathrm{~g}$, and consists of a thick fleshy skin or peel (30-40\% of total fruit weight), typically have high sugar (10\% of total rind weight) content (Ali, 2001). Prickly pears (Opuntia spp., Cactaceae) have a fundamental economic importance in many desert areas, which are produced in abundant quantities (Ali, 2001 and EL-Nagmy et al., 2001).

Analysis of the main constituents of prickly pear peel showed a significant amount of polysaccharides $(21 \%)$, cellulose $(29.1 \%)$, hemicelluloses $(8.5 \%)$, pectin $(3 \%)$, protein $(8.3 \%)$ and minerals $(12.13 \%$, on dry matter) (El Kossori et al., 1998). They added that prickly pear covered have included significant amounts of pigments and flavour compounds, particularly betalains, polyphenols. The lipid content in the peel fraction was reported to be $2.43 \%$ (on dry weight basis). Several researches showed that the prickly pear is a very rich plant in vitamins, minerals, amino acids and sugars. It has been used as foodstuffs for medical applications cosmetics and for production of the cochineal (Stintzing and Scheiber, 2003). Elhassaneen, et al. (2016a) showed that PPP has been considered as a good source of dietary fibers and bioactive compounds such as carotenoids and phenolics.

El Kholy (1999) found that PPP are rich in vitamins A and E and free from alkaloids as antinutritional factors. A number of studies have demonstrated that proximate chemical composition of PPP on air dry matter basis was 7.20 to 10.21 , and 2.00 to $3.85 \%, 10.45$ to 14.33 and 8.02 to15.80, respectively, for CP, EE, CF and ash (Ali, 2001; El-Nagmy et al., 2001 and Ragab, 2007). Also, PPP contains reasonable amount of NFE being 48.89\% (Ragab, 2007). Ragab (2007 and 2012) indicated that PPP contained true metabolizable energy (ME) 2800 to $2850 \mathrm{Kcal} / \mathrm{kg}$ on DM basis. Recently, Anwar and Sallam (2016) showed that the chemical composition of PPP being have moisture $75.8 \%$, protein $4.56 \%$, lipid $3.66 \%$, fiber $7.72 \%$, ash 8.66 , total sugar $60.65 \%$, total fiber $32.67 \%$, ascorbic acid $87.82 \%$ and pectin $14.25 \%$.

Cactus is a desertification plant spaces and a highly palatable to wild and domesticated rabbits (Hoffman et al., 1993). Prickly pears is particularly attractive as a feed because of its high efficiency in converting water to dry matter and thus digestible energy (El-Kholy, 1999). Cardador-Martínez et al. (2011) reported that Cactus pear antioxidant capacity was higher in its peel than in the seeds. Recently, phenolic and flavonoid compounds have attracted much interest because they are potent antioxidants and exhibit various other physiological activities including anti-inflammatory, antimicrobial, antiallergic, anticarcinogenic and antihypertensive activities (Diaz-Vela, et al., 2013). Cactus pear by-products can indeed be exploited as a good and cheap source of natural antioxidants and antibacterial (Cardador-Martínez, et al. 2011 and Koubaa, et al., 2015).

The pods of the plant are used as animal fodder (Crosta and Vecchio, 1979 and Badr et. al., 2017a). ElNagmi et al. (2001) found that peels of prickly pear contained $61.57 \% \mathrm{NFE}$ and $2800 \mathrm{Kcal} / \mathrm{kg}$, as ME. Schaffer, et al. (2005) and Osorio-Esquivel, et al. (2011) reported that Cactus contains substantial amounts of ascorbic acid, fibers, amino acids, vitamin E, carotenoids and antioxidant compounds (phenols and flavonoids). Peels are promising fruit by-products because of their high content of insoluble and dietary fiber, pectin and fructooligosaccharides, as well as phenolic compounds, proteins, lipids, minerals and vitamins (Nawirska and Kwasniewska, 2005; Espırito Santo et al., 2012). Cactus pear peel accounts for around $60 \%$ of the fruit and is an important source of carbohydrates, polyunsaturated fatty acids and natural antioxidants like tocopherol and vitamins C and E (Ramadan and Mörcel, 2003 and Cerezal and Duarte, 2005). Ragab (2007) reported that the best performance was seen when 15\% PPP was incorporated in quail diets. 
The objective of this study was to examine the effects of prickly pear peel (PPP) levels in the diets of growing rabbits on the production performance, nutrient digestibility, blood constitutes, immunity and economic efficiency.

\section{MATERIALS AND METHODS}

The present study was carried out in the Rabbit farm of Animal Production Department Faculty of Agriculture Ain Shams University.

\section{Experimental animals:}

Sixty male New Zealand White (NZW) weaned aged 35 days and weighed $600 \mathrm{~g} \pm 2.20$ on average were equally and randomly divided into four groups (15 in each).

\section{Collection peels:}

Peels of prickly pear (PPP) were collected from the sellers and then spread on a clean floor for sun drying. After complete dryness, the material was ground and stored until formulating the experimental diets.

\section{Feeding trial management:}

Feed and water were offered ad libitum throughout the experimental period that continued along 5 to 14 weeks of rabbits age. All rabbits were nearly equal in live body weight at the beginning of the experiment. All nutrients, essential amino acids, minerals and vitamins in the experimental diets were adjusted according to the rabbit requirements of NRC (1977). Passably all experimental animals were healthy and clinically free from internal and external parasites and were kept under the same management and hygienic conditions. Table (2) shows the composition and calculated analysis of the experimental diets. The first group was fed ad libitum, throughout experiment period on a commercial pelleted diet and kept untreated and served as a control. While the tested groups (second, third and fourth) were fed the diets which included 10, 20 or 30\% dried prickly pear peel (PPP), respectively as shown in Table (2) .

\section{Growth performance:}

Rabbits were weighed in the morning before receiving feed or water and feed intake was recorded biweekly during the experimental period. Body weight gain (BWG) and feed conversion ratio (FCR) were calculated and recorded over along the experimental period. Also, performance index (PI) was calculated according to North (1981). Average protein and digestible energy intakes were calculated by multiplying feed intake by percent of protein and digestible energy contents of experimental diets.

\section{Digestibility trial:}

The collection period lasted for 5 days. Feed intake was measured and feces output was collected daily. Hair and scattered feed were separated or taken out of the feces. The collected feces for rabbits of each treatment was pooled together, and dried at $60^{\circ} \mathrm{C}$ till constant weight. The dried feces for the successive five days was left few hours to get equilibrium with the atmosphere and then ground, well mixed and stored in screw-top glass jars for chemical analysis. Chemical analysis was carried out for diets and faeces according to methods of AOAC (2000). The values of total digestible nutrients (TDN) and digestible crude protein (DCP) were calculated according to the classic formula (Cheeke et al., 1982). DE (kcal/kg DM) $=4253-32.6$ (CF \%) -144.4 (Ash \%), according to Fekete and Gippert (1986).

\section{Cecum samples:}

Samples of cecum content were individually taken from rabbits of each group directly after slaughtering and filtrated to estimate $\mathrm{pH}$ and cecum micro flora. Cecum ammonia-nitrogen determination was carried out as soon as possible using the steam distillation method described by Ahmed (1976). While cecum totals volatile fatty acids (VFA's) content was measured according to AOAC (2000). The microbial content of the caecum of the same slaughtered rabbits (6 rabbits /diet) was estimated in their selective media, as described by Bryant and Robinson (1961) for total microbial count. 
Table (1): Chemical analysis of prickly pear peels (PPP) \% (on DM basis).

\begin{tabular}{lccccccccc}
\hline Item & OM & CP & EE & CF & NFE & NDF & ADF & Ash & ME $^{*}$ \\
\hline Prickly pear peels & 83.29 & 9.80 & 2.41 & 16.72 & 54.36 & 60.48 & 34.70 & 16.71 & 2944 \\
\hline${ }^{*}$ Calculated according to Carpenter and Clegg (1956) by applying the equation
\end{tabular}

$M E(\mathrm{Kcal} / \mathrm{kg})=(35.3 \times \mathrm{CP} \%)+(79.5 X \mathrm{EE} \%)+(40.6$ X NFE \% $)+199$.

Table (2): Composition and calculated analysis of the experimental diets.

\begin{tabular}{|c|c|c|c|c|}
\hline \multirow[t]{2}{*}{ Item } & \multirow{2}{*}{$\begin{array}{l}\text { Control } \\
\text { (C) }\end{array}$} & \multicolumn{3}{|c|}{ Prickly pear peels \% (PPP) } \\
\hline & & 10 & 20 & 30 \\
\hline \multicolumn{5}{|l|}{ Ingredient, \% } \\
\hline Yellow corn & 6.40 & 2.00 & 2.90 & 2.00 \\
\hline Soybean meal (48\%) & 5.50 & 5.50 & 9.73 & 13.00 \\
\hline Wheat bran & 31.74 & 23.73 & 12.50 & 10.00 \\
\hline Corn gluten $60 \%$ & 4.50 & 5.50 & 4.50 & 3.50 \\
\hline Clover hay & 38.66 & 37.68 & 36.68 & 30.30 \\
\hline Barley & 7.00 & 9.40 & 7.50 & 5.00 \\
\hline Molasses & 3.00 & 3.00 & 3.00 & 3.00 \\
\hline Prickly pear peels & - & 10 & 20 & 30 \\
\hline L-Lysine $\mathrm{HCl}$ & 0.05 & 0.04 & 0.04 & 0.05 \\
\hline Limestone & 1.0 & 1.0 & 1.0 & 1.00 \\
\hline Dicalcium-phosphate & 1.50 & 1.50 & 1.50 & 1.50 \\
\hline $\mathrm{NaCl}$ & 0.35 & 0.35 & 0.35 & 0.35 \\
\hline Premix ${ }^{*}$ & 0.30 & 0.30 & 0.30 & 0.30 \\
\hline Total & 100 & 100 & 100 & 100 \\
\hline \multicolumn{5}{|l|}{ Calculated analysis** } \\
\hline $\mathrm{DE}, \mathrm{Kcal} / \mathrm{Kg}$ & 2510 & 2509 & 2511 & 2513 \\
\hline Crude protein $(\mathrm{CP})$ & 17.1 & 17.00 & 17.2 & 17.3 \\
\hline Ether extract (EE) & 2.41 & 2.29 & 2.19 & 2.13 \\
\hline NFE & 56.34 & 55.43 & 53.79 & 53.46 \\
\hline \multicolumn{5}{|l|}{ Fiber fractions: } \\
\hline Crude fiber $(\mathrm{CF})$ & 14.2 & 14.6 & 14.6 & 14.1 \\
\hline NDF $\%$ & 36.15 & 38.84 & 40.15 & 41.33 \\
\hline $\mathrm{ADF} \%$ & 21.46 & 23.48 & 25.16 & 25.67 \\
\hline Hemicellulose & 14.69 & 15.32 & 14.91 & 15.54 \\
\hline Cellulose & 10.98 & 12.70 & 14.20 & 15.56 \\
\hline ADL $\%$ & 10.48 & 10.82 & 11.04 & 10.23 \\
\hline $\mathrm{Ca} \%$ & 1.31 & 1.40 & 1.49 & 1.52 \\
\hline Total P \% & 0.46 & 0.47 & 0.48 & 0.50 \\
\hline Lys \% & 0.46 & 0.41 & 0.47 & 0.55 \\
\hline Meth \% & 0.19 & 0.19 & 0.18 & 0.18 \\
\hline Price/ton & 4106 & 4050 & 4120 & 4200 \\
\hline
\end{tabular}

* Each $3 \mathrm{~kg}$ of vit and Min in Premix contain: 6000000IU vit A, $900000 \mathrm{IU}$ vit D3 40000mg vit E,2000mg vit K, $2000 \mathrm{mg}$ vit.B1, 4000mg vit B2, 2000mg vit B6, 10mg vit B12, 50000mg Niacin, $10000 \mathrm{mg}$ pantothenic acid, 50mg Biotin, $3000 \mathrm{mg}$ Folic acid, $250000 \mathrm{mg}$ choline, 50000mg Zn, 8500mg Mn, 50000mg Fe, 50000mg Cu, 200mg I, 100mg Se and 100mg Co.

** According to NRC (1977).

NDF: neutral detergent fiber; $A D F$ : acid detergent fiber; $A D L:$ acid detergent lignin.

\section{Carcass characteristics:}

At the end of the experimental period (14 weeks of age) a total number of 20 rabbits (five rabbits from each group) were randomly taken for slaughtering test. Assigned rabbits were fasted for 16 hours before slaughtering and individually weighed as pre-slaughter weight. Animals were slaughtered by cutting the jugular veins of the neck and left for a uitale time for complete bleeding was achieved and then slaughter weight was recorded. After skinning, the carcass was opened down and all entrails were removed and the 
empty carcass, heart, liver, kidneys and spleen were separately weighed and each of them was proportioned to the live pre-slaughter weight. Dressing percentage was calculated according to Steven et al. (1981).

\section{Biochemical parameters:}

Blood samples were taken at the time of slaughter and then centrifuged at 3000 r.p.m. for 20 minutes to obtain plasma and kept at $-20{ }^{\circ} \mathrm{C}$ and until analysis. Blood plasma was assigned for determination of total protein, albumin, total lipids and liver function (aspartate aminotransferase "AST" and alanine aminotransferase "ALT") by commercial kits. Non-coagulated blood was tested shortly after collection for estimating blood pictures. Plasma immunoglobulin, IgG and IgM in plasma were employed using the method of Leslie and Frank (1989). White and red blood cells were counted according to Feldman et al. (2000).

\section{Enzymes activity:}

The pancreas and GIT segments sampling procedure was estimated by using the method according to Uni et al. (1999). Both of pancreatic and tissue samples were homogenized in ice-cold 0.2 MTris -HCl buffer, $\mathrm{pH} 8.0$, containing $0.05 \mathrm{M} \mathrm{NaCl}$ in the ratio $1: 4$ (wt. /vol.). The homogenate sample was centrifuged at $3000 x$ for 15 minutes at $4^{\circ} \mathrm{C}$, the supernatant was stored frozen $\left(-70^{\circ} \mathrm{C}\right)$ for enzymes assay. The homogeneous intestinal digesta samples were collected by massaging the tract from the distal end of the duodenum to the ileocecal junction according to the method of Jin et al. (2000).

All samples were diluted 10-folds, based on the weight of the sample, with ice-cold PBS (pH 7.0), and homogenized for one minute and solicited for 1 min with 3 cycles at 30 -s intervals. All samples were centrifuged at $18000 \mathrm{x}$ g for $20 \mathrm{~min}$ at $4^{\circ} \mathrm{C}$. The supernatants were classified into small portions and then stored at $-70^{\circ} \mathrm{C}$ to enzymes assay. Amylase activity in sera, tissues, and digesta was determined using the method of Somogyi (1960). The activity of lipase was assayed by using the method described by Tietz and Fiereck (1966), while the activity of Protease was analyzed by using the method of Lynn and ClevetteRadford (1984).

\section{Statistical analysis:} model:

Data were statistically analyzed according to SPSS (2012) computer program using the following fixed

$$
Y i j=\mu+T_{i}+e_{i j}
$$

Where: $\mathrm{Yij}=$ the observation; $\mu=$ overall mean; $\mathrm{T}_{\mathrm{i}}=$ effect of treatments; $\mathrm{e}_{\mathrm{ij}}=$ random error component assumed to be normally distributed.

Duncan's multiple range tests was performed (Duncan, 1955) to detect significant differences among means.

\section{RESULTS AND DISCUSSION}

\section{Chemical composition of prickly pear peels (PPP):}

The chemical composition of PPP content presented in Table (1) where in the peel was contained $9.80 \%$, $2.41 \%, 16.72 \%, 54.36 \%$ and $16.71 \%$ for CP, EE, CF, NFE and ash, respectively. While, Ragab (2007) found that PPP contains $10.21 \%$ CP, 3.85\% EE, 48.89\% NFE and $10.45 \%$ CF. Likewise, El Kossori et al. (2000) recorded moderate values of CP and ash in PPP being $8.30 \%$ and $12.13 \%$, respectively. Anwar and Sallam (2016) showed that the chemical composition of PPP content is as follows: moisture $75.8 \%$, protein $4.56 \%$, lipid $3.66 \%$, fiber $7.72 \%$, ash 8.66 , total sugar $60.65 \%$, total dietary fiber $32.67 \%$, Ascorbic acid $87.82 \%$ and pectin $14.25 \%$. Also, they added that prickly pear peel had high contents of fiber, pectin, Ascorbic acid and phenolic components. One of the main characteristics of these ingredients is the relatively high-soluble carbohydrate content, rendering them more fermentable by lactic acid bacteria, these results agree with Badr et. al. (2017a).

Badr et al. (2017b) showed that PPPs is a source of protein (4.75\%), carbohydrates $(59.25 \%)$, calcium (2.04\%), iron $(80.35 \mathrm{mg} / \mathrm{kg})$, zinc $(37.49 \mathrm{mg} / \mathrm{kg})$, copper $(1.92 \mathrm{mg} / \mathrm{kg})$, phosphorous $(0.9 \%)$, betaglucan 


\section{El-Neney et al.}

$(27.25 \%)$ and $\beta$-carotene $(141.4 \mu \mathrm{g} / 100 \mathrm{~g})$. PPPs content of hemicellulose, cellulose and lignin were $0.5,10.92 \%$ and $1.2 \%$, respectively

These contradictions of results about CP, CF, and ash contents of PPP indicated that chemical composition of PPP are very heterogeneous depending on surrounding environmental conditions and age.

\section{Growth Performance:}

Live body weight and total body weight gain of NZW rabbits are illustrated in Table (3). The final body weight, total body weight gain and performance index values were significant higher levels of dried PPP 20 and 30\% supplementation than those a control. While the same values of the low level of PPP - ration (10\%) did not significant different than those a control. In relation to some forage, Ruiz-Feria et al. (1998) reported that rabbits fed leucaena in their ration had the poorest performance, in comparison with those fed diet including $10 \%$ cactus as a replacement ingredient. In agreement with the present results, Taddesse, et al. (2014) reported that supplemented spineless cactus goats $(150 \mathrm{~g} / \mathrm{head} / \mathrm{d}$ cactus $)$ had higher final BW and mean daily BW gain as compared to the control. On the other hand, El-Nagmy et al. (2001) and Ragab (2012) reported that no significant differences in LBW and LBWG due to feeding quail and male chicks on diet supplemented with PPP ingredient.

Table (3): Effect of dietary prickly pear peels level (PPP) on growth performance of growing rabbits.

\begin{tabular}{|c|c|c|c|c|c|c|}
\hline \multirow{2}{*}{ Item } & \multirow[b]{2}{*}{ Control } & \multicolumn{3}{|c|}{ Levels of PPP\% } & \multirow[t]{2}{*}{ SEM } & \multirow[t]{2}{*}{ Sig. } \\
\hline & & 10 & 20 & 30 & & \\
\hline No. of rabbits & 15 & 15 & 15 & 15 & - & - \\
\hline Experimental period (day) & 63 & 63 & 63 & 63 & - & - \\
\hline Initial live body weight $(\mathrm{g})$ & 600 & 602 & 598 & 601 & 2.20 & NS \\
\hline Final live body weight (g) & $1990^{\mathrm{c}}$ & $2000^{\mathrm{c}}$ & $2080^{\mathrm{b}}$ & $2178^{\mathrm{a}}$ & 10.00 & $*$ \\
\hline Total weight gain $(\mathrm{g})$ & $1390^{\mathrm{c}}$ & $1398^{\mathrm{c}}$ & $1482^{\mathrm{b}}$ & $1577^{\mathrm{a}}$ & 15.60 & $*$ \\
\hline Total feed intake $(\mathrm{g})$ & $4905^{\mathrm{a}}$ & $4754^{\mathrm{b}}$ & $4646^{\mathrm{c}}$ & $4597^{\mathrm{d}}$ & 6.22 & $*$ \\
\hline Feed conversion ratio, $\mathrm{g}$ feed/g gain & $3.53^{\mathrm{a}}$ & $3.40^{\mathrm{a}}$ & $3.13^{\mathrm{b}}$ & $2.92^{c}$ & 0.12 & $*$ \\
\hline Protein intake $(\mathrm{g})$ & $838.76^{\mathrm{a}}$ & $808.18^{b}$ & $799.11^{\mathrm{bc}}$ & $795.28^{c}$ & 7.10 & $*$ \\
\hline Digestible Energy intake (kcal) & $12312^{\mathrm{a}}$ & $11928^{\mathrm{b}}$ & $11666^{\mathrm{c}}$ & $11552^{c}$ & 22.14 & $*$ \\
\hline Performance index (PI)\% ${ }^{1}$ & $56.37^{\mathrm{c}}$ & $58.82^{c}$ & $66.45^{\mathrm{b}}$ & $74.59^{\mathrm{a}}$ & 5.50 & $*$ \\
\hline
\end{tabular}

${ }^{a, b, c, d}$ :Means in the same row bearing different superscripts are significantly different.

$* *: P \leq 0.01, *: P \leq 0.05$, NS: not significant.

${ }^{I} P I=($ Body weight $(\mathrm{kg}) /$ Feed conversion $) \times 100$.

Improvement growth performance may be attributed to mode of action of PPP including maintaining a beneficial microbial population and improving the digestibility of the diet. The increased live weight gain in rabbits fed on PPP diets can be explained by the positive associative effects of high soluble carbohydrates of the cactus ingredient. Also, cactus is a desertification plant and being a highly palatable component to the wild and domesticated rabbits. Prickly pear peels are an important source of several nutritional substances like pectin, mucilage, minerals, pigments and flavor compounds, particularly betalains and polyphenols. The lipid content in the peel fraction was estimated to be $2.43 \%$ (on dry weight basis). Several researches showed that prickly pear is a very rich plant in vitamins, minerals, amino acids and sugars. It is used as foodstuffs for medical applications cosmetics and for production of the cochineal (Stintzing and Scheiber, 2003). Elhassaneen, et al. (2016 a and b) showed that PPP was characterized as good source of dietary fibers and bioactive compounds such as carotenoids and phenolic.

These increments in growth performance traits may be attributed to increasing the digestibility of all nutrients the tested diet (Table, 4) decreasing pH, NH3-N (mmol/l) (Table, 5). Also, decreasing NH3-N concentration and the increasing of VFA in the cecum considerably reflected positively on nutrients utilization and the conversion of ammonia- $\mathrm{N}$ into microbial protein throughout the pseudo-rumination processes which considered a key and critical part in the digestive system in rabbits.

\section{Feed intake and feed conversion:}

Estimations of total feed intake, protein intake, digestible energy intake and feed conversion measurement are presented in Table (3). Total feed intake and digestible energy intake were significant decreased with increasing PPP level in the tested rations. Similar trend was observed with protein intake 
among the experimental treatments where its intake was significant decreased with increasing PPP level in the tested rations. The decrease of feed intake in rabbit fed PPP could be explained by the increase in nutrients supply such as minerals and water soluble vitamins that could accelerate nutrients metabolism and increase energy digestibility. Also, PPP can improve the conditions of the intestines and enhances the average daily weight gain and digestibility. This may be due to the many positive factors in this by-product i.e. the high fiber content (16.72, CF and 34.70, ADF) which is associated with ME (2944). The high fiber level may induce a high digestibility of the diets associated with a lower FI and higher efficiency of feed utilization. These results are in agreement with the findings of Ali (2001), Abu Shammalah (2007) and Zeedan et al. (2015).

Table (4): Digestibility and feeding values of the experimental rations.

\begin{tabular}{lcccccc}
\hline \multirow{2}{*}{ Item } & \multicolumn{3}{c}{ Levels of PPP\% } & & SEM & \multirow{2}{*}{ Sig. } \\
\cline { 3 - 5 } & Control & 10 & 20 & 30 & & \\
\hline Digestion coefficient (\%) & & & & & & \\
DM & $65.50^{\mathrm{b}}$ & $66.20^{\mathrm{b}}$ & $67.10^{\mathrm{b}}$ & $72.01^{\mathrm{a}}$ & 0.98 & $*$ \\
CP & $70.01^{\mathrm{b}}$ & $70.12^{\mathrm{b}}$ & $73.12^{\mathrm{b}}$ & $79.10^{\mathrm{a}}$ & 1.00 & $*$ \\
EE & $72.22^{\mathrm{c}}$ & $73.00^{\mathrm{bc}}$ & $75.33^{\mathrm{b}}$ & $80.00^{\mathrm{a}}$ & 0.85 & $*$ \\
NFE & 66.50 & 66.62 & 67.70 & 69.65 & 1.50 & NS \\
CF & $36.30^{\mathrm{b}}$ & $36.50^{\mathrm{b}}$ & $38.50^{\mathrm{b}}$ & $43.75^{\mathrm{a}}$ & 0.76 & $*$ \\
Feeding values & & & & & & $*$ \\
TDN, \% & $58.51^{\mathrm{b}}$ & $57.94^{\mathrm{b}}$ & $58.63^{\mathrm{ab}}$ & $60.92^{\mathrm{a}}$ & 0.75 & $*$ \\
DCP, \% & $11.97^{\mathrm{b}}$ & $11.92^{\mathrm{b}}$ & $12.58^{\mathrm{b}}$ & $13.68^{\mathrm{a}}$ & 0.02 & $*$ \\
DE (kcal/ kg) & $2574^{\mathrm{b}}$ & $2549^{\mathrm{b}}$ & $2580^{\mathrm{b}}$ & $2680^{\mathrm{a}}$ & 9.10 & $*$ \\
\hline
\end{tabular}

${ }^{a, b, c}:$ Means in the same row bearing different superscripts are significantly different.

$*: P \leq 0.05$, NS: not significant.

${ }^{* * *} \mathrm{DE}(\mathrm{kcal} / \mathrm{kg})=T D N \times 4400(\mathrm{NRC}, 1985)$.

The feed conversion measurement in the present study rabbits fed 30\% PPP diet recorded significantly the best FCR values among the dietary regarding treatments, being 3.53, 3.40, 3.13 and $2.92 \mathrm{~g}$ feed/ g gain, for control, 10, 20 and 30\% PPP, respectively. Also, the 20\% PPP ration had significant better value respecting FCR than that of control. The increase PPP level significantly $(\mathrm{P} \leq 0.05)$ improved feed conversion compared to control diet (Table 3). These findings are very consistent with those reported by Abu Shammalah (2007) who found that feed conversion ratios in rabbits fed the control diet without or with $20 \%$, $40 \%$ or $60 \%$ cactus were $3.33,3.01,2.85$ and 3.25, respectively. Similarly, Zeedan et al. (2015) reported that feed conversion ratios in rabbits were $3.41,3.26,2.99$ and $2.74 \%$ for the control or tested ration contained 10, 20 and 30\%, cactus opuntia cladodes, respectively. However, El-Nagmy et al. (2001) reported no significant differences in FC values due to feeding quail chicks on different levels of PPP in their diets.

The improvement in FCR with PPP inclusion may be due to the improvement of their crude protein digestibility and nutrient utilization due to the flavonoids and phenolic acids which involved in PPP. Also, the improvement of FCR due to PPP inclusion levels may be due to a beneficial effect of microbial environment in the gut, which might have enhanced digestion, absorption and utilization of nutrients. Also, the improvement in FCR may be due to the antioxidant, antibacterial, antimicrobial and anti-inflammatory activities as well as nutrient utilization that depended on the presence of flavonoids and phenolic acids (Ennouri et al., 2014).

\section{Digestibility and Feeding Value:}

Data of digestibility and feeding value of the experimental rations are presented in (Table 4). The results showed that the digestibility of most nutrients were significantly increased only with the $30 \%$ PPP- tested ration compared with those of control. Insignificant increases in most nutrient digestibilities were observed with 10 and $20 \%$ - tested rations in comparison of these of control. These results are in agreement with the findings reported by Einkamerer (2008), Costa et al. (2012) and Zeedan et al. (2015).

Despite the low nutrimental quality of the prickly pear cactus, its modulatory effects including better digestibility and high fermentative capacity of its carbohydrates (Misra et al., 2006). Digestible organic matter is important for ruminal microbial protein synthesis as an energy source. This difference may 


\section{El-Neney et al.}

be due to the high content of non-structural carbohydrates (NSC) that found in cactus plants. Definitely, Tegegne, et al. (2005) reported that the high concentration of soluble carbohydrates in cactus could be facilitate the incorporation of nitrogen into microbial protein, which is the main source of metabolizable protein for the host animal. The highest digestibility of all nutrients in tested rations can be discussed from the point that prickly pear cactus containing minerals, amino acids, high malic acid contents, vitamin A, vitamin $\mathrm{E}$, vitamin $\mathrm{C}$, flavonoid, carotenoids and phenolic constituents, which may be associated with improvement in digestibility of all nutrients (Cardador-Martínez et al., 2011 Espirito Santo et al., 2012 and Cordova-Torres et al., 2015). Furthermore improvement of nutrient digestibilities could be reflected positively on growth performance of rabbits where such action might be due to that PPP are rich in amino acids, vitamins and minerals in addition to its antioxidant and antimicrobial properties.

Presumably, the compounds with antimicrobial effect maintained the health of the digestive gut and improved both digestion and absorption. A one reason of increasing the might be resulted from the reduction of intake that occurred due to the addition of PPP in the tested rations. It is well documented that digestibility of the diet increases with decreasing intake (NRC, 1977).

In this study, the results showed that the use of PPP improved digestibility of nutrients and absorption and this reaction can lead to increase feed utilization and improve the production performance.

\section{Cecum Traits:}

Data presented in Table (5) indicated that cecal $\mathrm{pH}$ value ammonia-N concentrations, E. coli count and total anaerobic bacteria for treated groups especially 20 and $30 \%$ PPP were significantly $(\mathrm{P}<0.05)$ decreased than those of the control. While, the differences between the low levels PPP - rations 10\% PPP and control did not significant respecting such mentioned items. Cecum $\mathrm{pH}$ value is one of the most important factors, which affect microbial fermentation in the cecum and influences their functions. The decreased cecal $\mathrm{pH}$ and E. coli count for rabbits treated with PPP could be attributed to more fermentation of the caecal leading to reduce caecal $\mathrm{pH}$ as a result of increasing volatile fatty acids production. Also cecal $\mathrm{pH}$ value in rabbits depends on some factors such as the level of diet intake and its composition. The fluctuations in the $\mathrm{pH}$ value could reflect the changes of organic acids accumulated in the ingesta. Likewise PPP has been characterized as good source of dietary fiber that enhancing the intestinal health. These results are in agreement with those reported by Zeedan, et al. (2015) with rabbits, Mendez-Llorente, et al. (2008) with sheep and Vieira et al. (2008) with goats. On the other hand, Misra, et al. (2006) found that ruminal NH3-N concentration was not significantly different between lambs fed 0,10 and 20\% prickly pear cactus, but were higher than that of the levels of 30 and $40 \%$. On the present study higher PPP levels in the tested rations 30 and $40 \%$ significantly increased $(\mathrm{P} \leq 0.05)$ the concentration of total VFA compared to that of control ration. The application of PPP in the diets of rabbit's is probably the most interest to rabbit's producers as an antimicrobial and antioxidants factors. The flavonoids / phenolic components also play a significant role in the free radical scavenging capacity of PPP.

Table (5): Effect of dietary prickly pear peels level (PPP) on cecum traits of growing rabbits.

\begin{tabular}{|c|c|c|c|c|c|c|}
\hline \multirow[t]{2}{*}{ Item } & \multirow[b]{2}{*}{ Control } & \multicolumn{3}{|c|}{ Levels of PPP\% } & \multirow[t]{2}{*}{;EM } & \multirow[t]{2}{*}{ Sig. } \\
\hline & & 10 & 20 & 30 & & \\
\hline Cecum $\mathrm{pH}$ & $6.84^{\mathrm{a}}$ & $6.72^{\mathrm{a}}$ & $6.40^{\mathrm{a}}$ & $5.35^{b}$ & 0.11 & 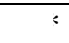 \\
\hline Bacteria count E.coli $\times 10^{2} \mathrm{CFU} / \mathrm{g}$ & $810.1^{\mathrm{a}}$ & $811.0^{\mathrm{a}}$ & $752.5^{\mathrm{b}}$ & $63.2^{\mathrm{c}}$ & 10.0 & s \\
\hline Total anaerobic bacteria $\times 10^{6} \mathrm{CFU} / \mathrm{g}$ & $8.54^{\mathrm{a}}$ & $8.50^{\mathrm{a}}$ & $7.26^{\mathrm{b}}$ & $4.98^{\mathrm{c}}$ & 0.10 & s \\
\hline Total microbial count $\times 10^{5} \mathrm{CFUml}^{-1}$ & $9.95^{\mathrm{c}}$ & $10.38^{\mathrm{c}}$ & $16.84^{\mathrm{b}}$ & $8.65^{\mathrm{a}}$ & 1.50 & : \\
\hline $\mathrm{NH}_{3}-\mathrm{N}(\mathrm{mmol} / \mathrm{l})$ & $21.10^{\mathrm{a}}$ & $20.85^{\mathrm{a}}$ & $17.00^{\mathrm{b}}$ & $5.18^{\mathrm{c}}$ & 0.32 & 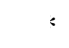 \\
\hline Total VFA (mmol/l) & $41.20^{\mathrm{c}}$ & $42.12^{\mathrm{c}}$ & $56.20^{\mathrm{b}}$ & $6.31^{\mathrm{a}}$ & 2.10 & $s$ \\
\hline
\end{tabular}

The decreased cecum $\mathrm{pH}$ and could be entail the ammonia-N concentration and the increased the VFA concentration suggest active microbial synthesis existed in the cecum. Also, decreasing NH3-N concentration might be attributed to the conversion of ammonia-N into microbial protein that being beneficial for rabbits productive performance. Such profound modulatory effect that characterizing the biologically pseudo-rumination process improve the nutrient digestibility's as shown in Table (4). On the 
other hand, Ben Salem and Smith (2008) reported that the high content of sugars in cactus pear did not affect ruminal fermentation in sheep.

\section{Carcass characteristics and chemical composition:}

Analysis of variance showed that significant variation among the dietary treatments of PPP for most carcass characteristics (Table 6). Rabbits received 30\% PPP-ration had the highest values respecting carcass weight, dressing percentage and spleen\% in corresponding values of the other tested treatments and control one, that had the lowest ones. The abdominal fat $\%$ had the vice versa trend, where the control had the highest percentage of fat. The increase in carcass traits for treated groups may be mainly related to the increase in growth performance and digestibility. These results confirmed partially those of Mahouachi, et al. (2012) and Zeedan, et al. (2015). Ragab (2007 and 2012) concluded that PPP used in ration formulation of Japanese quails can substitute up to $30 \%$ of yellow corn at 14 to 70 days of age without any detrimental effect on slaughter parameters of Japanese quails and Hy-Line W-36 male chick. Ruiz-Feria et al. (1998) evaluated that rabbits fed catus as forage had the poorest performance, but when fed $10 \%$ level cactus, growth and carcass traits were improved. Abu Shammalah (2007) found that the carcass weight and spleen weight of rabbits significantly affect $(\mathrm{P}<0.05)$ with cactus supplementation.

Table (6): Effect of dietary prickly pear peels level (PPP) on some carcass traits of growing rabbits.

\begin{tabular}{lcccccc}
\hline Item & & \multicolumn{3}{c}{ Levels of PPP\% } & SEM & \multirow{2}{*}{ Sig. } \\
\cline { 3 - 5 } & Control & 10 & 20 & 30 & & \\
\hline Carcass weight, g & $1150^{\mathrm{c}}$ & $1161^{\mathrm{c}}$ & $1183^{\mathrm{b}}$ & $1298^{\mathrm{a}}$ & 8.54 & $*$ \\
Dressing, \% & $57.05^{\mathrm{b}}$ & $57.86^{\mathrm{b}}$ & $57.98^{\mathrm{b}}$ & $61.70^{\mathrm{a}}$ & 1.60 & $*$ \\
Spleen \% & $0.05^{\mathrm{b}}$ & $0.06^{\mathrm{b}}$ & $0.08^{\mathrm{a}}$ & $0.08^{\mathrm{a}}$ & 0.001 & $*$ \\
Abdominal fat (\%) & $0.80^{\mathrm{a}}$ & $0.70^{\mathrm{b}}$ & $0.68^{\mathrm{b}}$ & $0.58^{\mathrm{c}}$ & 0.01 & $*$ \\
Chemical analysis of carcass meat on DM basis & & & & & \\
CP, \% & $21.32^{\mathrm{d}}$ & $21.35^{\mathrm{d}}$ & $22.42^{\mathrm{c}}$ & $22.70^{\mathrm{b}}$ & 0.10 & $*$ \\
EE, \% & $3.01^{\mathrm{a}}$ & $2.86^{\mathrm{a}}$ & $2.55^{\mathrm{b}}$ & $2.30^{\mathrm{c}}$ & 0.01 & $*$ \\
Ash, \% & 1.32 & 1.25 & 1.27 & 1.30 & 0.03 & NS \\
\hline
\end{tabular}

$a, b, c, d$ :Means in the same row bearing different superscripts are significantly different.

$*: P \leq 0.05$, NS: not significant.

Lower abdominal fat percent obtained with administration PPP in rabbit diet might be due to the lower digestible energy intake by rabbits compared to that of control as shown in Table (3). These results are in agreement with those reported by Atti et al. (2006), Mahouachi, et al. (2012) and Zeedan, et al. (2015).

Generally the increase in carcass traits with lower abdominal fat percent in tested groups diets can be affected favorably by the vital contents of PPP i.e minerals, amino acids, malic acid, vitamin A, vitamin E, vitamin C, flavonoid, carotenoids and phenolic constituents, which may be associated with improvement in digestibility of all nutrients (Abu Shammalah, 2007, Cardador-Martínez et al., 2011, Espirito Santo et al., 2012 and Cordova-Torres et al., 2015).

Concerning the chemical analysis for carcass meat (Table 6), the results showed that significant effect was found as feeding PPP inclusion where with in crude protein (CP) and ether extract (EE) of meat. These results are in agreement with those reported by Ragab (2012) and Zeedan, et al. (2015).

\section{Blood constituents:}

Blood plasma parameters are presented in Table (7). Mostly, the concentrations of plasma total protein, albumin and globulin were significant higher with the tested ration (10,20 and 30\%) than those of control, being the highest values were associated with 30\% PPP-ration followed by 20 and $10 \%$ and then control This result is in harmony with findings of Zeedan, et al. (2015).

Globulin was significantly increased by using PPP and it means that immunity of rabbits fed PPP was improved compared to that of control group.

Blood plasma of total lipids was significantly decreased by increasing PPP inclusion level compared to that of control group. These may be due high contents of fiber, ascorbic acid and phenolic components in PPP ingredient. 


\section{El-Neney et al.}

Liver function indicators as AST and ALT activities were not affected by the dietary treatments with supplementing PPP. These results are in agreement with the findings of Ragab (2012) and Zeedan, et al. (2015). Values of AST and ALT were within the normal range and indicated that the animals were generally in a good nutritional status and their livers were in a normal health condition. The protective effect of PPP upon some organs such as liver and brain may be due to its contents of some flavonoids such as quercerin and rutin which play a potential role as antioxidant against oxidative material which caused damage to such organs. On the other hand, Ragab (2007), with Japanese quail and Elhassaneen et al. (2016a and b) with rats suggested that plasma AST and ALT were increased by addition of PPP in their diets. In relation to the vital components of PPP, El-Nashar (2007) found that flavonoids have exhibited strong antioxidant activity against reactive oxygen species in vitro. The hepatoprotective activity of flavonoids was possibly due to its antioxidant properties that acting as scavengers of reactive oxygen species. Also, treatment with prickly pear fruit significantly $(\mathrm{P}<0.05)$ decreased the elevated AST and ALT almost to normal levels in Rats (Abd El-Razek and Hassan, 2011).

Table (7): Effect of dietary prickly pear peels level (PPP) on some biochemical concentrations in blood plasma, enzymatic activity and blood picture of growing NZW rabbits.

\begin{tabular}{|c|c|c|c|c|c|c|}
\hline \multirow[t]{2}{*}{ Item } & \multirow[b]{2}{*}{ Control } & \multicolumn{3}{|c|}{ Levels of PPP\% } & \multirow[t]{2}{*}{ SEM } & \multirow[t]{2}{*}{ Sig } \\
\hline & & 10 & 20 & 30 & & \\
\hline Total protein $(\mathrm{mg} / 100 \mathrm{ml})$ & $5.90^{\mathrm{b}}$ & $6.30^{\mathrm{b}}$ & $6.80^{\mathrm{a}}$ & $7.20^{\mathrm{a}}$ & 0.03 & $*$ \\
\hline Albumin $(\mathrm{mg} / 100 \mathrm{ml})$ & $2.40^{\mathrm{b}}$ & $3.10^{\mathrm{a}}$ & $3.30^{\mathrm{a}}$ & $3.40^{\mathrm{a}}$ & 0.01 & $*$ \\
\hline Globulin (mg/100ml) & $2.50^{\mathrm{c}}$ & $3.20^{\mathrm{b}}$ & $3.50^{\mathrm{ab}}$ & $3.60^{\mathrm{a}}$ & 0.01 & * \\
\hline Total lipids (mg/dl) & $466.88^{\mathrm{a}}$ & $431.61^{b}$ & $400.15^{\mathrm{c}}$ & $398.50^{\mathrm{c}}$ & 5.01 & * \\
\hline \multicolumn{7}{|l|}{ Enzymatic activity: } \\
\hline $\operatorname{AST}(\mathrm{U} / \mathrm{L})$ & 24.44 & 23.98 & 24.66 & 25.10 & 0.50 & NS \\
\hline ALT (U/ L) & 15.43 & 15.70 & 15.88 & 16.20 & 0.66 & NS \\
\hline \multicolumn{7}{|l|}{ Blood picture: } \\
\hline Hemoglobin $(\mathrm{g} / \mathrm{dl})$ & $10.50^{\mathrm{d}}$ & $11.50^{\mathrm{c}}$ & $12.00^{\mathrm{b}}$ & $12.75^{\mathrm{a}}$ & 0.02 & * \\
\hline Red blood cells $\left(\mathrm{N} \times 10^{6} / \mathrm{mm}^{3}\right)$ & $5.20^{\mathrm{c}}$ & $5.37^{\mathrm{c}}$ & $6.05^{\mathrm{b}}$ & $6.68^{\mathrm{a}}$ & 0.03 & $*$ \\
\hline White blood cells $\left(\mathrm{N} \times 10^{3} / \mathrm{mm}^{3}\right)$ & $4.75^{\mathrm{c}}$ & $5.20^{\mathrm{bc}}$ & $5.50^{\mathrm{b}}$ & $6.55^{\mathrm{a}}$ & 0.08 & * \\
\hline $\operatorname{IgG}(\mathrm{mg} / \mathrm{ml})$ & $2.77 \mathrm{c}$ & $3.85 b$ & $4.01 \mathrm{~b}$ & $5.44 \mathrm{a}$ & 0.01 & $*$ \\
\hline $\operatorname{IgM}(\mathrm{mg} / \mathrm{ml})$ & $1.10 \mathrm{~d}$ & $1.55 \mathrm{c}$ & $2.05 \mathrm{~b}$ & $3.10 \mathrm{a}$ & 0.01 & $*$ \\
\hline
\end{tabular}

Data in Table (7) show that, values of each of blood components including (red and white blood cells count) and hemoglobin were increased in rabbits fed diet contained PPP than those of the control. The increase in hemoglobin and WBCs in treated groups can be attributed mainly to the antibacterial functions, antimicrobial, anti-inflammatory activity and antioxidant of PPP (Ennouri et al., 2014).

Concerning immunoglobulin (IgG and $\operatorname{IgM}$,) concentrations in the plasma of rabbits (Table 7) its values were significant higher for rabbits supplemented their diets with the different levels of PPP than those of control group. The improved blood components as a result of dietary treatment with PPP may be due to the improvement in the immune response (minerals and flavonoids have a role in enhancing the immune system). These results are agreement with those of Zeedan et al. (2015). Abu Shammalah (2007), Cardador-Martínez et al. (2011) and Cordova-Torres et al. (2015) they reported that possible explanation of the observed increase of IgG and IgM with increasing PPP levels may be amino acids, vitamins and trace elements of PPP absorption due the stimulus to the development, proliferation and differentiation of intestinal cells and because they improve the environmental conditions for the intestinal microbial ecosystem. PPP can also improve the cell immune response, the antibody production speed and reinforce the immunological system. No doubt, flavonoids and phenolic acids are major classes of polyphenolic compounds, whose structure-antioxidant activity relationships in aqueous or lipophilic systems have been extensively.

Cactus opuntia peels may possess a significant amounts of antibacterial, antimicrobial, anti-inflammatory and antioxidant substances. These components tended to be increased with the improvement of digestibility and efficiency of nutrition absorption and utilization thus may be reflected on better performance of 
production. Also, it may be probably led to an increase in the absorption rate from the digestive tract, thus blood constituents of the treatment animals reflected a corresponding increase of these values.

The improvements in the blood components as a result of treatment with PPP may be due to improvement in the immune response (minerals and flavonoids have a role in enhancing immune system). Inclusion of the minerals composition are comprised of ( $\mathrm{Mg}, \mathrm{Ca}, \mathrm{K}, \mathrm{Na}, \mathrm{Cu}, \mathrm{Zn}, \mathrm{Mn}, \mathrm{P}$ and $\mathrm{Fe}$ ) vitamin $\mathrm{A}$, vitamin E, vitamin C, carotenoids, phenolic constituents and flavonoid (Abu Shammalah, 2007, CardadorMartínez et al., 2011, Espirito Santo et al., 2012 and Cordova-Torres et al., 2015.

\section{Enzymes activity:}

Table (8) shows the activity of certain digestive enzymes in pancreatic tissue and intestinal contents.Incorporation of PPP in diets shows a significant increase in the activity of intestinal amylase, lipase and protease in rabbits compared to controls. At the same time, activities of amylase, lipase, and protease in pancreatic tissue homogenates were observed to be significantly higher as compared to control rabbits.

Table (8): Activity of digestive enzymes in rabbits as affected by prickly pear peels level (PPP) at the end of experimental period.

\begin{tabular}{lcccccc}
\hline & \multicolumn{7}{c}{ Digestive enzymes } \\
\cline { 2 - 6 } Group & \multicolumn{7}{c}{ Intestinal content (U/g) } & Pancreas (U/g) \\
\cline { 2 - 6 } & \multicolumn{7}{c}{ Amylase } & Lipase & Protease \\
\cline { 2 - 6 } & \multicolumn{7}{c}{ Amylase } & Lipase & Protease & $260.33^{\mathrm{c}}$ & $80.77^{\mathrm{c}}$ & $81.88^{\mathrm{c}}$ \\
\hline Control & $87.98^{\mathrm{c}}$ & $61.72^{\mathrm{b}}$ & $55.60^{\mathrm{c}}$ & $288.51^{\mathrm{b}}$ & $110.30^{\mathrm{b}}$ & $99.25^{\mathrm{c}}$ \\
$10 \%$, PPP & $99.87^{\mathrm{bc}}$ & $62.55^{\mathrm{b}}$ & $63.04^{\mathrm{c}}$ & $298.98^{\mathrm{ab}}$ & $155.69^{\mathrm{a}}$ & $118.96^{\mathrm{b}}$ \\
$20 \%$, PPP & $115.60^{\mathrm{b}}$ & $89.55^{\mathrm{a}}$ & $75.14^{\mathrm{b}}$ & $309.31^{\mathrm{a}}$ & $158.08^{\mathrm{a}}$ & $139.80^{\mathrm{a}}$ \\
$30 \%$, PPP & $145.33^{\mathrm{a}}$ & $98.70^{\mathrm{a}}$ & $94.60^{\mathrm{a}}$ & 3.92 & 3.87 & 5.22 \\
SEM & 6.90 & 2.80 & 1.10 & $*$ & $*$ & $*$ \\
Sig. & $*$ & $*$ & $*$ & $*$ & & $*$ \\
\hline
\end{tabular}

${ }_{a, b, c}:$ Means in the same column bearing different superscripts are significantly different.

*: $P \leq 0.05$.

The increased enzymatic activities in the intestinal content might be contributed to the sum of exogenous and endogenous enzymes action. Another possible factor responsible for such an increased enzymatic activity could be the 'favorable change in $\mathrm{pH}$ of GI tract' mediated by exogenous enzymes Moreover, the increased availability of nutrients (substrates) inside the GIT, most probably, the cause of increased activity and secretion of such digestive enzymes from the glandular mother cells (exocrine pancreatic cells) as a positive feedback response which is mainly neural factors instead of gut hormones (Murai et al., 2000). Onderci et al. (2006) who pointed out that a large portion of the digestive enzymes secreted by the pancreas are absorbed into blood and recycled in an enteropancreatic circulation.

This positive influence of PPP on the activity of enzymes may be due to the supplementary role on the overall digestive kinetic action causing an enhancement of the titers of digestive enzymes in pancreatic tissue and intestinal content.

On the other hand, the antimicrobial properties of PPP could be caused by weakens the growth of most pathogenic bacteria, and this leads to optimal enzyme activity. Nonetheless, the compounds with antimicrobial effect maintained the health of the digestive tract and improved digestion, absorption and activities of the digestive enzymes in pancreatic tissue and intestinal contents. Specifically, the associative effects between the feed ingredients can modify the metabolic processes and the digestive enzymes in the gastrointestinal tract according.

\section{Economical efficiency:}

Results in Table (9) show that economical efficiency values during the period from 5 to 14 weeks of age was marked improved with rabbits fed diets contained 10,20 and 30\% PPP as compared with those fed the control diet. Rabbits fed diet 30\% PPP had the best economical and relative efficiency values being 2.11 and $130 \%$, respectively followed by rabbits fed diet with 20\% PPP (1.94 and $120 \%$, 


\section{El-Neney et al.}

respectively) then rabbits fed diet 10\% PPP (1.76 and $108 \%$, respectively) as compared with rabbits fed control diet. This is logical since the tested material (PPP) has low or no price compared to the rest of feed ingredients so any addition level would be lowering feed cost, and thus increasing the economic efficiency. Similar results with other agricultural by-products supplemented with PPP were reported by Ragab (2012) and Zeedan et al. (2015) for cactus pear. Badr et al. (2017a) showed that the potential value of PPPs as a good natural source of energy and nutritive components and appear to be promising package from the nutritional and economical point of view and introduce two complete rations for different purposes of productions for dry season feeding systems that could enhance productivity of livestock.

Table (9): Effect of dietary prickly pear peels level (PPP) on the relative economical efficiency of growing rabbits.

\begin{tabular}{lcccc}
\hline \multirow{2}{*}{ Item } & & \multicolumn{3}{c}{ Levels of PPP\% } \\
\cline { 3 - 5 } & Control & 10 & 20 & 30 \\
\hline Total feed intake /rabbit (kg) & 4905 & 4754 & 4646 & 4597 \\
Price/kg diet (LE) & 4.11 & 4.05 & 4.12 & 4.20 \\
Total feed cost/rabbit (LE) & 20.16 & 19.25 & 19.14 & 19.30 \\
Total weight gain (kg) & 1.390 & 1.398 & 1.482 & 1.577 \\
Price/kg body weight (LE) & 38.00 & 38.00 & 38.00 & 38.00 \\
Selling price (L.E) & 52.82 & 53.12 & 56.32 & 59.93 \\
Net revenue (LE) & 32.66 & 33.87 & 37.18 & 40.63 \\
Economic efficiency* & 1.62 & 1.76 & 1.94 & 2.11 \\
Relative economical efficiency (\%) & 100 & 108 & 120 & 130 \\
\hline
\end{tabular}

*Net revenue/Total cost.

\section{CONCLUSION}

In conclusion, it could be potentially using up to $30 \%$ prickly pear peels in diet for growing rabbits without any adverse effect on health. The dietary PPP will have a positive influence on the health primarily aiming to improve immune status of rabbits improve their growth performances, digestibility and feeding value, cecum traits, carcass characteristics, some blood constituents, activity of certain digestive enzymes in pancreatic tissue and intestinal contents and economical efficiency. However, there is a need of doing more research to confirm these results, not only on fattening rabbits, but also with the other classes of livestock considering different levels of cactus residuals.

\section{REFERENCES}

Abdel-Hameed, E. S., S. A. Bazaid and M. S. Salman (2013). Characterization of the phytochemical constituents of Taif rose and its antioxidant and anticancer activities. BioMed Res. Int. http://dx.doi.org/10.1155/2013/345465 (Article ID 345465, 13 pages).

Abd El-Razek, F. H. and A. H. Hassan (2011). Nutritional value and hypoglycemic effect of prickly cactus pear) opuntiaficus-indica) fruit juice in alloxan-induced diabetic Rats. Australian Journal of Basic and Applied Sciences, 5(10): 356-377.

Abu Shammalah, K. N. (2007). Evaluation of Cactus (Opuntia Sp.) as Forage Source for Growing Rabbits in the Gaza Strip. M.Sc. Thesis, the Islamic Univ. -Gaza, Faculty of Sci. Master of Biological Sci.

Ali, A. M. (2001). Replacing yellow corn with peels of prickly pear in quail ration in north Sinai. Egypt. Poult. Sci. Vol. 21 (IV): 963 - 975.

Ahmed, B. M. (1976). The use of non-protein nitrogenous compounds in rabbit rations. M. Sc. Thesis. Tanta Univ. 
Anwar, M. M. and E. M. Sallam (2016). Utilization of prickly pear peels to improve quality of pan bread. Arab J. Nucl. Sci. and Appl., 94 (2) :( 151-163).

AOAC (2000). Association of Official Analytical Chemists. Official Methods of analysis. $15^{\text {th }}$ Edition. Washington, D.C., U.S.A.

Arrizon, J.; Calderón, C. and G. Sandoval (2006). Effect of different fermentation conditions on the kinetic parameters and production of volatile compounds during the elaboration of a prickly pear distilled beverage. Journal of Industrial Microbiology and Biotechnology, v. 33(11): 921-928.

Atti, N., M. Mahouachi and H. Rouissi (2006). The effect of spineless cactus (Opuntia ficus-indica f. intermis) supplementation on growth, carcass, meat quality and fatty acid composition of male goat kids. Meat Sci. 73: 229-235.

Badr, S. E. A.; A. A. bakr and M. M. El-Shinnawy (2017a). prediction the nutritive value of prickly pear peels as a natural unconventional feed resource for feeding ruminants from chemical composition and in vitro digestibility using daisy ii incubator. Egyptian J. Nut. and Feeds, 20 (2): 47-58.

Badr, S. E. A.; A.A. bakr, Gihan M. El-moghazy and O. A. Wahdan (2017b). Anticancer activity and hypolipidemic effect of methanolic and ethanolic prickly pear cactus peel extracts. Egypt. Nut. Society Issue. The first International conference of nutrition, Hurghada, April

Ben Salem, H. and T. Smith (2008). Feeding strategies to increase small ruminant production in dry environments. Small Rum. Res. 77: 174-194.

Bryant, M.P. and I. M. Robinson (1961). An improved nonselective culture medium for ruminal bacteria and its use in determining diurnal variation in numbers of bacteria in the rumen. J. Dairy Sci., 44:1446.

Cardador-Martínez, A., C. Jiménez-Martínez and G. Sandoval (2011). Revalorization of cactus pear (Opuntia spp.) wastes as a source of antioxidants. Ciênc. Tecnol. Aliment, Campinas, 31(3): 782-788.

Cerezal, P. and G. Duarte (2005). Use of skin in the elaboration of concentrated products of cactus pear (Opuntia ficus-indica (L.) Miller). Journal of the Professional Association for Cactus Development, 7:6183.

Cheeke, P. R.; N. M. Patton and G. S. Tempelton (1982). Rabbit Production. $5^{\text {th }}$ Edition, Interstate Printers and Publishers Danville II., USA.

Cordova-Torres, A.V., J. C. Mendoza-Mendoza, G. Bernal-Santos, T. García-Gasca, J. R. Kawas, R. G. Costa, C. Mondragon Jacoboa and H. M. Andrade-Montemayor (2015). Nutritional Composition, in vitro Degradability and Gas Production of Opuntia ficus indica and Four Other Wild Cacti Species. Life Sci. J. $12(2 \mathrm{~s}): 42-54$.

Costa, R. G., I. H. Trevino, G. R. de Medeiros, A. N. Medeiros, T. F. Pinto, and R. L. de Oliveira (2012). Effects of replacing corn with cactus pear (Opuntia ficus indica Mill) on the performance of Santa Inês lambs. Small Rum. Res. 102: 13- 17.

Crosta, G.; and V. Vecchio (1979). Use of Opuntia ficus-indiea as cattle feed inArid Regions. Rivista di Agricltura SubtropicaleTropicale. 73:79.

Diaz-Vela, J., A. Totosaus, A. E. Cruz-Guerrero, M. de Lourdes and Pérez-Chabela (2013). In vitro evaluation of the fermentation of added-value agroindustrial by-products: cactus pear (Opuntia ficusindica L.) peel and pineapple (Ananas comosus) peel as functional ingredient. Int. J. Food Sci. and Tech. 48:1460-1467.

Duncan, D. B.(1955). Multiple range and multiple F test, Biometrics 11:1-42.

EAS (2012). Bulletin of estimates agricultural income. (In Arabic). Economic Affairs Sector (EAS). Ministry of Agric. And Land Reclamation. Cairo. Egypt, (22): 54.

Einkamerer, O. B. (2008). Animal performance and utilization of Opuntia-based diets by sheep. M.Sc. Agric. Thesis. Univ. of the Free State, Bloemfontein, S. Afr.

El-Beltagi, H. S., I. M. Heba, A. Elmelegy, S. Eldesoky and G. Safwat (2019). Phytochemical screening, antimicrobial, antiaxidant, anticancer activities and nutritional values of cactus) opuntia ficus indicia) pulp and peel. FEB, 28 ( 2A): 1534-1551. 


\section{El-Neney et al.}

Elhassaneen, Y., S. Goarge, R. Sayed and M. Younis (2016a). Onion, Orange and Prickly Pear Peel Extracts Mixed with Beef Meatballs Ameliorate the Effect of Alloxan Induced Diabetic Rats. American J. of Pharmacology and Phytotherapy, (1):15-24

Elhassaneen, Y.; R. Sherif and M. Raghda (2016b). Improvement of Bioactive Compounds Content and Antioxidant Properties in Crackers with the Incorporation of Prickly Pear and Potato Peels Powder. Int. J. Nut. And Food Sci. 5(1): 53-61.

El Kossori, R. L., C. Sanchez, E. Boustani and M. N. Maucourt (2000). Comparison of effects of prickly pear (Opuntia ficus indica sp) fruit, arabic gum, carrageenan, alginic acid, locust bean gum and citrus pectin on viscosity and in vitro digestibility of casein. J. Sci. Food and Agric. 80(3):359 - 364.

El Kossori, R. L., C. Villaume, E. Boustani, Y. Sauveaire and L. Mejean (1998). Composition of pulp, skin and seeds of prickly pear fruit (Opuntia ficus indica sp.). Plant Foods for Human Nutrition; (52):263-70.

El-Nashar, N. G. (2007). Development of primary liver cell culture from fish as a valuable tool in nutrition and biotechnology research. Ph.D. Thesis, Faculty of Home Economics, Minoufiya University, Shebin El-Kom, Egypt.

El Kholy, K. F. (1999). The use of some nonconvential feed sources in fish nutrition. Ph.D. Thesis, Faculty of agriculture Cairo University.

El-Nagmi, K. Y.; A. M. Ali and M. S. Abd-Elmalak (2001). The effect of using some untraditional feedstuffs on the performance of Japanese quails in north sinai. Egypt. Poult. Sci. 21: 701-717.

Ennouri, M.; I. Ammar, B. Khemakhem and H. Attia (2014). Chemical Composition and Antibacterial Activity of Opuntia Ficus-Indica F. Inermis (Cactus Pear) Flowers. J. Med. Food, 17:908-914.

Espírito Santo, A. P., N. S. Cartolano, T. F. Silva, F. A. S. M. Soares, L. A. Gioielli, A. Converti and M. N. Oliveira (2012). Fibers from fruit by-products enhance probiotic viability and fatty acid profile and increase CLA content in yoghurts .International Journal of food Microbiology, 154, 135-144.

Felker, P. (1995). Forage and fodder production and utilization. In: Agro-ecology, culture and uses of cactus pear. pp. 144.

Fekete, S and T. Gippert (1986). Digestibility and nutritive value of nineteen feedstuffs. J. Appl. Rabbit Res., 9: 103- 108.

Feldman, B. F.; J. G. Zinkl and N. C. Jain (2000). Schalm's Veterinary Hematology. Lippincott Williams and Wilkins, Philadelphia, USA.

Hoffman, M. T., C. D. James, G. I. H. Kerley and W.G. Whitford (1993). Rabbit herbivory and its effect on cladode, flower and fruit production of opuntia violacea var macrocentra (cactaceae) in the northern Chihuahuan desert, New Mexico. The southwestern Naturalist, 38 (4): 309-315.

Jin, J., Y. W. Ho., Abdullah, N. and Jalaludin, S. (2000). Digestive and bacterial enzyme activities in broilers fed diets supplemented with lactobacillus cultures. Poult. Sci., 79:886-891.

Koubaa, M., A. Ktata, F. Bouaziz, D. Driss, R. E. Ghorbe and S. Chaabouni (2015). Solvent extract from Opuntia stricta fruit peels: Chemical composition and Biological activities. Free Rad. Antiox. 5 (2):5259.

Kuti, J. O. (2004). Antioxidant compounds from four Opuntia cactus pear fruit varieties. Food Chemistry, 85:527-533.

Leslie, H. and C. H. Frank (1989). Practical Immunology. Third ed. pp. 23.

Lynn, K. R. and N. A. Clevette-Radford (1984). Purification and characterization of hevin, a serin protease from Heveabrazilliensis. Biochem. J., 23:963-964.

Mahouachi, M., N. Atti and H. Hajji (2012). Use of spineless cactus (opuntia ficus indica f. inermis) for dairy goats and growing kids: impacts on milk production, kid's growth, and meat quality. The Scientific World J. Volume 2012, Article ID 321567, 4 pages. doi:10.1100/2012/321567.

Mendez-Llorente, F., R.G. Ramírez-Lozano, J. I. Aguilera-Soto and C.F. Arechiga-Flores (2008). Performance and nutrient digestion of lambs fed incremental levels of wild cactus (Opuntia leucotrichia). 
Conference on International Research on Food Security, Natural Resource Management and Rural Development, Univ. of Hohenheim, 7-9.

Misra, A. K., A. S. Mishra, M. K. Tripathi, O. H. Chaturvedi, S. Vaithiyanathan, R. Prasad and R. C. Jakhmola (2006). Intake, digestion and microbial protein synthesis in sheep on hay supplemented with prickly pear cactus [Opuntia ficus-indica (L.) Mill.] with or without groundnut meal. Small Rum. Res. 63:125-134.

Murai, A., S. Satoh, J. Okumura and M. Furuse (2000). Factors regulating amylase secretion from chicken pancreatic acini in vitro . Life Sci., 66:585-591.

Nawirska, A. and M. Kwaśniewska (2005). Dietary fibre fractions from fruit and vegetable processing waste. Food Chem. 91, 221-225.

North, M. O. (1981). Commercial chicken production. Annual. $2^{\text {nd }}$ Edition. Av. Publishing company I. N. C., West-post Connecticut. U.S.A.

NRC (1977). National Research Council: Nutrient Requirements of Rabbits. $2^{\text {nd }}$ Revised Edition, National Academy of Sciences, Washington, DC. USA.

Onderci, M., N. Sahin, K. Sahin, G. Cikim and A. Aydin (2006). Efficacy of supplementation of alphaamylase-producing bacterial culture on the performance, nutrient use and gut morphology of broiler chickens fed a corn-based diet. Poult. Sci., 85: 505-510.

Osorio-Esquivel, O.; A. Ortiz-Moreno; V.B. Álvarez, L. Dorantes-Álvarez and M. M. Giusti (2011). Phenolics, betacyanins and antioxidant activity in Opuntia joconostle fruits. Food Res. Int. 44, 21602168.

Ragab, M. S. (2007). Replacing yellow corn with prickly pear peels in growing Japanese quail diets with or without enzyme supplementation .Fayoum J. Agric. Res. \& Dev. (21): 97-112.

Ragab, M. S. (2012). Effect of partially replacing of yellow corn with prickly pear peels on the growth performance of Hy-line W-36 male chicks. Egypan J. Nutrion and Feeds (15): 361-373.

Ramadan, M. F. and J. T. Mörcel (2003). Recovered lipids from prickly pear (Opuntia ficus-indica (L.) Miller) peel: a good source of polyunsaturated fatty acids, natural antioxidant vitamins and sterols. Food Chemistry, 83, 447-456.

Ruiz-Feria, C. A., S. D. Lukefahr and P. Felker (1998). Evaluation of Leucaena leucocephala and catus as forages for growing rabbits. Livestock Res. for Rural Development. http://www.cipav.org.co/lrrd//rrd10/2/luke102.htm.

Schaffer, S.; S. Schmitt-Schillig, W. E. Müller and G. P. Eckert (2005). Antioxidant properties of Mediterranean food plant extracts: Geographical differences. J. Physiol. Pharmacol. 56 (Suppl. S1): $115-124$.

Somogyi, M. (1960). Modification of two methods for the assay of amylase. Clin. Chem., 6:23-27.

SPSS (2012). SPSS User's Guide Statistics Version 19. Copyright IBM, SPSS Inc., USA.

Steven, W. D.; W. D. Hohenboken, P. R. Cheeke, N. M. Patton and W. H. Kennick (1981). Carcass and meat characteristics of Flernish Giant and New Zealand White purebred and terminal cross rabbits. J. App. Rabbit Res., 4: 66.

Stintzing, F.C. and A. Scheiber (2003). Evaluation of color properties and chemical quality parameters of cactus juices. Eur. Food Res. Technol. 216, 303-311.

Taddesse, D., S. Melakub and Y. Mekashac (2014). Effect of Supplementation of Cactus and Selected Browses Mix on Feed Utilization of Somali Goats. American Scientific Res. J. for Eng., Tech. and Sci. 9 (1): 20-34.

Tegegne, F., C. Kijora and K. J. Peters (2005). Study on the effects of incorporating various levels of cactus pear (Opuntia ficus-indica) on the performance of sheep. Conf. on Inte. Agric. Res. for Development. Stuttgart-Hohenheim, October 11-13.

Tietz, N. W. and E. A. Fiereck (1966). A specific method for serum lipase determination. Clin.Chim.Acta, 13:352-355. http://dx.doi.org/10.1016/0009-8981(66)90215-4. 


\section{El-Neney et al.}

Uni, Z., Noy, Y. and D. Sklan (1999). Posthatch development of small intestinal function in the poultry. Poult. Sci., 78:215-222.

Vieira E. L., A. M. V. Batista, A. Guim, F. F. Carvalho, A. C. Nascimento, R. F. S. Araújo, and A. F. Mustafa (2008). Effects of hay inclusion on intake, in vivo nutrient utilization and ruminal fermentation of goats fed spineless cactus (Opuntia fícus-indica Mill) based diets. Anim. Feed Sci. Tech. 141: 199-208.

Zeedan, Kh. I. I., A. M. El-Neney, Battaa A. I., Abd El- Lateif, T. A. Nasra, Awadien and Ebeid (2015). Effect of using residues prickly pear as a source of dietary feedstuffs on productive performance, biological traits and immune response of rabbit.1- prickly pear cladodes. Egypt. Poult. Sci., 35: 933-953.

تأثير استخدام مخلفات التين الثوكى كمصدر علفى على الاداء الانتاجى والصفات الفسيولوجية والاستجابة

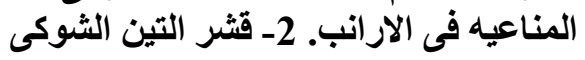

باتعة أحمد الننى1 ، خالد ابراهيم ابراهيم زيدان² ، عصام الكتامى² ، غادة جاد33 و عاصم عبده4 1 قسم بحوث تغذية الدواجن - معهل بحوث الإتتاج الحيواني- مركز البحوث الزراعيةـ الدقي- جيزة.

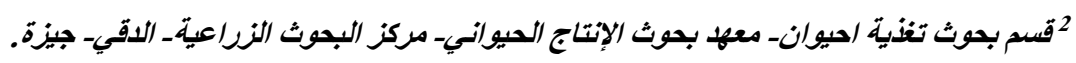

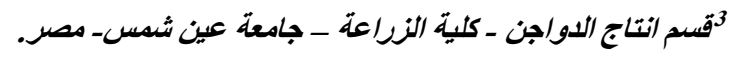

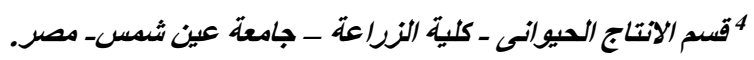

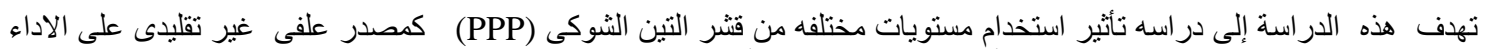

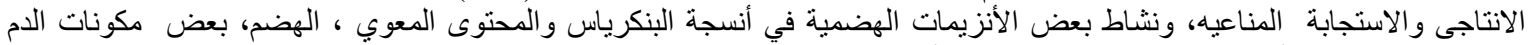

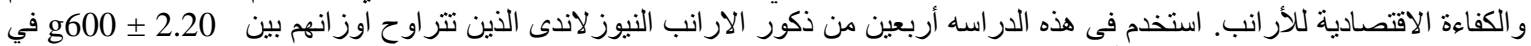

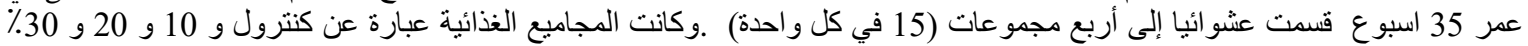

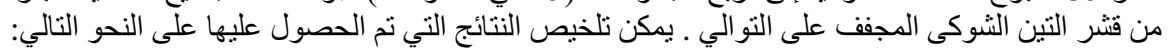

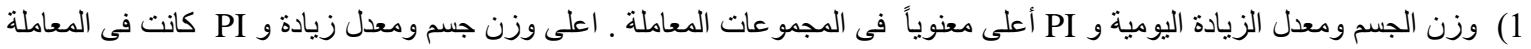

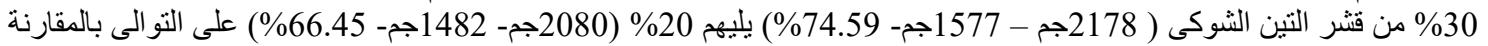

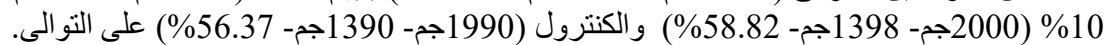
2) الغذاء المأكول والبروتين والطاقة المأكولة تقل معنويا مع زيادة مستوي التغذية على الواح التين الثوكى ـ وكفأه التحويل الغذائى كانت

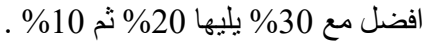

3) تحسنت معنويا قيم معاملات هضم (DM, CP, EE, CF, TDN, DCP and DE) لمحتوي المو اد الغذائيه للعلائق المعاملة بالواح التين الثوكى المجفف بالمقارنة بالكترول

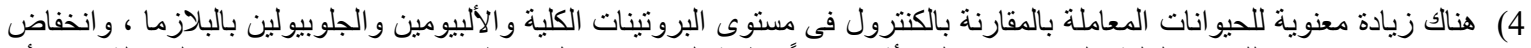

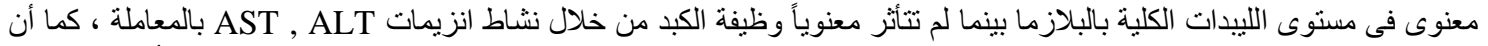

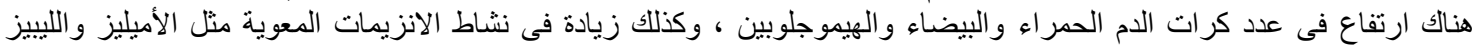

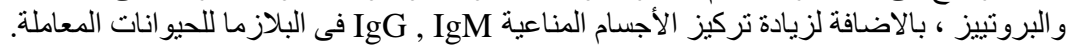

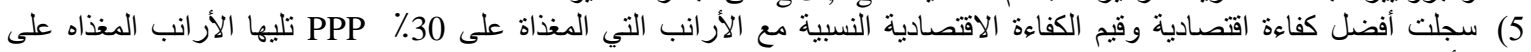

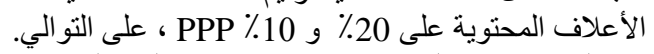
نستخلص من هذه الدراسه ان استخدام قشر التين الثوكى بمعدل 30 أو 20 ٪ فى علائق الارانب حسن الاداء الانتاجى والحالة الصحية 